\title{
Financial Incentives to Exporting SMEs in Emerging Countries
}

\author{
Isabel de Souza ${ }^{1}$ Dinora Eliete Floriani ${ }^{2}$ Felipe Mendes Borini ${ }^{3}$
}

${ }^{1}$ Universidade do Vale do Itajai - UNIVALI, e-mail: izabelrsouza@gmail.com
${ }^{2}$ Universidade do Vale do Itajai - UNIVALI, e-mail: dinora@univali.br
${ }^{3}$ Escola Superior de Propaganda e Marketing - ESPM, e-mail: fborini@espm.br

\section{KEYWORDS}

Financial Incentives; Exporting SMEs; Degree of Internationalization; Export Performance; Brazil paragraph.

Received 07.06.2014

Revised 14.11.2015

Accepted 04.04. 2016

DOI 10.7867/1980-4431.2015v20n2p31-39

ISSN 1980-4431

Double blind review

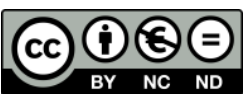

\section{ABSTRACT}

The purpose is to analyze whether use of government incentives by exporting SMEs in Brazil helps them increase their degree of internationalization (DOI) and/or improve their export performance. The regression model reveals that greater use of financial incentives was related to higher DOI and better performance. The results also indicate that the use of financial incentives provided by the Brazilian government help exporting companies, but does not present greater international competitiveness and where the lower the percentage funded higher is the degree of internationalization. The study is of quantitative predominance, with an exploratory research of a non-probabilistic sample chosen for convenience and accessibility. The sample was selected from a target population and data were collected through a structured questionnaire. As a suggestion for future work, the researchers plan to expand the research to large Brazilian companies, in order to examine whether financial incentives influence the degree of internationalization and export performance. The work has limitations with regard to the low number of companies that were willing to answer the questionnaire.

\section{Introduction}

Small and Medium Enterprises (SMEs) face obstacles and barriers making it difficult to reach a high degree of internationalization, but despite this they still participate in international business with persistence and creativity (McDOUGALL; OVIATT 1994). Notwithstanding, the extent to which SMEs are able to internationalize is limited by intrinsic capital shortages and the difficulties involved in adapting to environmental changes with the same speed with which larger companies are able to react, and this is equally true of national and international markets (MCDOUGALL; OVIATT, 1996). The reasons for the difficulties for exporting SMEs vary from lack of resources to internal and external risks. It can therefore be stated that the process of internationalization is a far greater challenge to SMEs than to larger companies.

Garcia (2007) has pointed out that government export incentive programs are one method for encouraging businesses to enter international markets, thereby becoming internationalized. These programs are designed to reduce some of the obstacles faced by businesses, including problems related to competitiveness. Financial incentives are intended to afford export products the necessary conditions to trade competitively on international markets. In view of this, this study was conducted in order to investigate whether financial incentives available in the Brazilian domestic market have an influence on the internationalization of Brazil's SMEs. 
Specifically, this paper attempts to answer the following three questions:

1) Do exporting SMEs that access more financial incentives have a higher degree of internationalization (DOI)?

2) Do SMEs that access more financial incentives have better export performance?

3) Do SMEs that access more financial incentives have better international competitiveness?

The data presented in this paper is interesting to the foreign SMEs that are thinking to invest in Brazil. SMEs that access more financial incentives have better export performance? 3) Do SMEs that access more financial incentives have better international competitiveness?

The data presented in this paper is interesting to the foreign SMEs that are thinking to invest in Brazil.

\section{Brazil and the exports SMEs}

The Brazilian government creates fiscal incentives and tax breaks in order to stimulate the local, national and international development needed to compete globally. These financial incentives have different characteristics because they are targeted at specific sizes of business: micro, small, medium or large. It is interesting to observe that government schemes of this type aim to increase the number of businesses trading on international markets, in particular SMEs, because they face many obstacles and barriers to entry into international markets.

According to Fleury et. al. (1981), the programs created by the Brazilian government are still insufficient to push many of these companies into international markets. An additional issue raised by businesses themselves is the lack of support and promotion for these programs. The result is that the export process is seen as something complex involving high costs and high risks. It is possible that more aggressive campaigns to promote these programs, conducted by the government and other institutions, could overcome the barrier of businessmen's ignorance of these programs. The result would be a greater number of SMEs taking part in the internationalization process (FLEURY et. al., 1981). Studies such as those published by Almeida (2007), Forte and Sette Jr (2005), Moreira (2009), Rocha (2003), Floriani (2010) Floriani and Fleury (2012) prove that SME participation in international markets is still rather incipient.

As it has already been highlighted by Johanson and Vahlne (2003), the internationalization process builds upon maturity and experience that a business acquires by exporting. In this view, an export strategy is relatively less demanding in terms of financial, organizational and administrative investment. It can therefore be seen as a more practical way for SMEs to gain entry to international markets, but this does not exempt national markets from the responsibility to create mechanisms to stimulate and promote the home nation exports.

In Brazil, both credit and financial incentives granted by the government to exporting businesses can be divided into short or long term loans. Short term funding is contracted at the true exchange rate prevailing at the time that funding is contracted or settled, and the exporting company chooses which financial institutions to approach. In contrast, long-term funding is available at interest rates that are subsidized by the federal government (BANCO DO BRASIL, 2011).

In partnership with other institutions, the government seeks to promote export ventures and considers exports to be an important factor for change that stimulates economic growth and improves employment rates and tax revenues (CZINKOTA; RONKAINEN, 1998) and so exportation is part of Brazil's trade policy.

There are several types of funding available on the Brazilian market designed to increase exports and improve the country's export performance. Pre-shipment programs are designed to support large-scale production, while postshipment programs are beneficial to exporters because they offer the clients long payment terms, but the exporters receive their money immediately (BNDES 2011). Chart 1 below summarizes some of the incentive and support programs available on the Brazilian market: It should be pointed out that the Brazilian government both runs programs to encourage companies to export and also provides financial resources to fund these exports with the objective of improving their competitiveness in international markets. This paper only investigates the financial incentives, in order to identify whether those SMEs that utilize them have a higher degree of internationalization and better export performance.

Revista de Negócios, v. 20, n. 2, p. 31-39, April, 2015. 
2.1 Degree of Internationalization and the questions of this study

For the purposes of this article, Dorrenbacher's (2000) proposal will be adopted, measuring DOI in terms of the volume of sales a company makes in international markets, the number of countries to which a firm exports and the number of employees a business has working internationally.

Notwithstanding, organizations still expect to be able to count on government financial incentives to increase their DOI, and this is particularly true of emerging countries such as Brazil.

The process of Intel's internationalization of Brazilian companies has been marked by factors that have had an influence on sales of their products on the export market. The most important of these factors are elements of macroeconomics. For example, in 1930 measures were introduced to protect the Brazilian industry with the intention of driving national industry. From 1950 to 1970 , there was a policy in favor of nationalized industries and government agencies and the Brazilian economy was closed to the outside world, which it meant that there was very little Brazilian participation on international markets. Years later the Brazilian industry was from the point of view of competitiveness, as a result of the restricted international interaction. In the mid-1970s, the Brazilian government attempted to rectify this situation with export incentives offering both tax breaks and credit. This policy resulted in a considerable number of Brazilian companies doing business abroad (GOULART; ARRUDA; BRAZIL, 1994).

It can, therefore, be stated that the Brazilian economic situation over this last decade has influenced many companies to seek out new markets expanding to other parameters of competition. After the Brazilian market was opened during the 1990s, companies exhibited rapid growth in response to measures to encourage international trade. (KUME 1996).

It should also be pointed out that this was a period of great importance during the history of the Brazilian economic development. Kume (1996) points out that opening the economy involved both a lowering of tariffs and also the removal of non-tariff-related barriers, encouraging economic growth. In other important positive effect was implementation of the Real Plan in 1994, which had the effect of expanding both national and international trade since it stimulated imports and introduced an exchange-rate policy designed to support Brazilian currency. (KUME 1996). Gomes, Silveira and Amal (2009) have pointed out that some studies published over recent years indicate that SMEs face several obstacles to becoming internationalized. However, according to Fleury et al. (1981) and Fleury and Fleury (2011), there is a failure on the part of government to adopt a more aggressive publicity policies with relation to their export incentive programs, providing SMEs with access to information and training to enable them to better make use of the financial incentives that are available on the Brazilian market.

The Fundação Dom Cabral (2010) surveyed companies that have gone through the process of internationalization and some of the most important barriers and difficulties that they described are as follows: a) organizational barriers (internal) related to the adequacy of organizational capacities and resources to doing business in international markets; b) barriers inherent to the Brazilian competitive environment, related to the adequacy of economic and institutional infrastructure, cultural characteristics and attitudes; and others such as barriers in the export market (whether economic, political-institutional or cultural).

Therefore, the objective of financial incentives is to allow companies to be able to rely on more appropriate conditions to allow them to face international competitiveness and make it possible for them to increase their investments abroad. (GARCIA 2007)

Given this measurement of DOI and considering the goals of export support programs and the financial incentive that the government offers to SMEs, it might be expected that these businesses can attain a satisfactory DOI if they assertively apply the resources available in the domestic market. Therefore: Q1: The more exporting SMEs use financial incentives the higher their DOI will be.

\subsection{Export Performance and Competitiveness}

It is also essential to bear in mind that it can be observed that some businesses achieve better

Revista de Negócios, v. 20, n. 2, p. 31-39, April, 2015. 
internationalization performance than others.

The EXPERF scale was developed during research conducted by Zou et al. (1998) to measure the difference in performance in firms' home countries and abroad. The scale consists of nine items to measure performance, each of which measures a component of financial or strategic performance or satisfaction with exports along a 7-point Likert scale.

Zou et al. (1998) demonstrated the effectiveness of their scale when analyzing the course of domestic and foreign performance. According to Cooper and Kleinschmidt (1985) the variables most often analyzed when measuring export performance of SMEs are export intensity and average growth in exports. Therefore, the performance metrics used in this study were selected from the model of performance variables constructed by Zou et al. (1998).

Internationalization of Brazilian companies has become a relevant subject for investigation in which the results show that there is a growth in these companies' insertion into the international market. In 2010, Brazil reported impressive figures for its participation in the international market, US\$ 257 billion, which was equivalent to $1.3 \%$ of world trade (MDIC, 2012).

Barney (1996) considers the question of performance to beat so important that one should provide parameters to evaluate the extent to which performance achieved is better than expected performance or the opposite. Many different variables have been used in the field to measure company performance. In the case of exporting companies, incentives available on the market may encourage private companies to increase their investments abroad, meaning that it may be possible to measure their performance in terms of their use of such benefits. Lopes and Gama (2007) have pointed out that certain key areas could be stimulated by management in order to improve company performance. These areas suggest standards and regulations to better deal with competitiveness. If these areas are in tune with each other, they can trigger better results from the internationalization process and improve company' performance. These areas are summarized in Table 1.

Financial incentives tend to favor and facilitate SMEs to enter the international market and to maintain an export with them and that is favorable to increasing their degree of internationalization and, consequently, their export performance. Floriani (2010) has emphasized how as SMEs' degree of internationalization increases its acquired experience which tends to make them more efficient and, consequently, improving their performance.

Q2: The more exporting SMEs use financial incentives the better their export performance will be.

Q3: The more exporting SMEs use financial incentives the better their export competitiveness will be.

\section{Methodology}

A theoretical-conceptual model illustrating the main constructs and variables related to financial incentives, the degree of internationalization, performance and competitiveness.

This model was designed specifically to investigate whether use of financial incentives influences the DOI, the export performance and/or the competitiveness of exporting SMEs from Santa Catarina state in Brazil. The model provides an overview of the variables that are involved in the financial incentives construct and the dependency relationships between DOI variables, export performance and competitiveness among SMEs from Santa Catarina that responded to a survey. The model was tested using a quantitative study design and an exploratory survey of a non-probabilistic sample chosen for convenience and accessibility. The sample was selected from a target population and data was collected using a structured questionnaire.

The population sampled was small and medium-sized exporters in Santa Catarina, of which, according to data from FIESC were 803. Phone calls were made to each company on the list of exporting SMEs in Santa Catarina provided by FIESC, in order to identify the true population to be investigated. After making numerous contacts, it was found that the population to be investigated fell from 803 businesses to 612 active exporting businesses. The person who replied at a further, eight of these businesses stated that company policy did not allow them to answer any type of questionnairs, while 142 businesses were no longer exporting, and 49 that were listed in

Revista de Negócios, v. 20, n. 2, p. 31-39, April, 2015. 
FIESC's database were not part of the population of interest. A final population of 604 businesses therefore remained. Data collection instruments were sent to these firms using Google Docs and emails. Data collection took place during the end of 2011 and 2012. A total of 70 questionnaires were completed by exporting SMEs in Santa Catarina.

\section{Results}

The sample studied here comprises 70 businesses that operate within international markets. Fifty-eight of these SMEs manufacture domestically and then export, while the remaining 12 have some type of international arm.

The state of Santa Catarina has many sectors that are suited to international trade, including the construction and building materials sector, the auto industry, textiles and clothing in general, lumber and furniture, the chemical industry and the food industry. Santa Catarina has the fifth largest industry of all of Brazil's states both in number of companies (43 thousand) and in number of workers (476 thousand). Notwithstanding, the state only accounts for $1.10 \%$ of Brazil's territory (SANTA CATARINA, BRASIL 2013). The most frequent types of businesses in the sample analyzed here were lumber and furniture companies (26\%) building materials companies (17\%) and textiles and clothing companies $(16 \%)$.

It is notable that $31.43 \%$ of the companies that took part export to one or two countries, while $17 \%$ export to 3 or 4 countries and only $14.29 \%$ of the SMEs export to more than 10 countries.

According to the respondent SMEs from Santa Catarina, the most common exported products are items such as electronic locks, wooden furniture, water cooler parts and accessories, paint and varnish, wooden frames, shoe stretchers, ceramic tiles, underwear and nightwear.

When SMEs were asked whether they have employees dedicated to managing export and trade negotiations in the international market or whether they subcontract these activities related to international markets, it was found that not all of these exporting businesses have their own export department. This data was used in the regression analysis to find out whether an internal export department influences these firms' performance and competitiveness.

During the nineteen-nineties, new businesses were established in many different sectors in Santa Catarina. Exporting businesses' revenues are seen as an important indicator since they are related to a company's expectations of remaining in international markets. It was found that $61 \%$ of the companies in this sample had annual revenues exceeding $\mathrm{R} \$ 251,000.00$, which shows that they are exporting significant volumes or that their products have high unit prices.

The SMEs from Santa Catarina were using a range of different export strategies. Direct export was the most commonly used method, adopted by $72 \%$ of businesses active in international markets and indirect exports accounted for $27 \%$. It can be observed that SMEs' subsidiaries are distributed in specific countries, such as in the South, Central and North America, among other continents. Small and medium enterprises have sought to install subsidiaries in countries far from Brazil. In the countries of the Mercosul, which are near to Brazil, 3 SMEs have subsidiaries in Argentina and there is only one in Paraguay.

In order to attempt to understand whether financial incentives influence SME's Degree of Internationalization and Export Performance, the respondents were asked the following questions: whether they were aware of the incentives; whether they utilize the incentives; what incentives they had used recently; which incentives they had already used; and which incentives they had never used. The results showed that the SMEs in Santa Catarina actually use ACEs. A total of $43 \%$ of these businesses ship the merchandise then collect the export documents and deposit them in a bank that deals with currency exchange, anticipating payment from customers who have negotiated payment terms. This means that almost $50 \%$ of businesses investigated are currently using ACEs (2013). However, $26 \%$ of the businesses had not used ACEs recently and $40 \%$ had never used them, making $66 \%$ of the businesses. This means that fewer companies are using this financial incentive than are not.

The ACC incentives are to fund production of goods and were being currently employed by $34 \%$ of the businesses, while $26 \%$ 
answered that they were not currently using them and $41 \%$ had never done so.

The PROEX export program is a government incentive that is notable because it offers advances against sales at lower interest rates than the two incentives mentioned above. However, only $20 \%$ of the SMEs researched were currently taking advantage of the PROEX offer, $26 \%$ were not currently utilizing it and $54 \%$ had never used PROEX. The large number of businesses that have never utilized this incentive may be related to the paperwork required to apply for this benefit, since this funding is from the national treasury and several different declarations of no outstanding federal debts are needed.

The Proger is a government incentive designed to generate employment and revenue by financing investment projects with working capital. None of the business surveyed were currently using the scheme, only $11 \%$ of the SMEs had ever used it and $89 \%$ had never used the Proger incentive. The program is currently closed to new applicants, which explains the large percentage of businesses that were not using it.

In summary, the main reason why exporting SMEs were not using any of the incentives mentioned is because a great deal of paperwork is involved and there are many obstacles to obtaining them. Notwithstanding, it is clear that the government needs to concentrate on mechanisms for publicizing these incentives better, since it is in the government's interest to promote Brazilian exports.

Having shown the macro figures above, the next task is to answer the question of whether SMEs that use more financial incentives have higher DOI, competitiveness and export performance. Table 1 shows figures for the regression models for dependent and independent variables.

It can be observed from these results that the variable "use of financial incentives" is meaningful and has an influence on DOI, showing that the greater the use of financial incentives, the higher the DOI. The variable "\% exports financed" exhibits a meaningful negative influence but is not significant for explaining DOI. The incentives ACC, ACE, Proex and Proger were not significant, and the results do not explain whether the use of any of these incentives increases DOI.
Model 2 was obtained when analyzing whether the more SMEs use financial incentives, the better their export performance would be. Analysis of the variable "use of incentives" once more showed that use of financial incentives has positive effects on export performance. This means that these variables have a meaningful influence on the export performance of SMEs from Santa Catarina. This result is shown by the significance of $\mathrm{p}$, which is the significance of a unitary variation in financial incentives. None of the other variables had a significant relationship with export performance.

Statistical tests showed that the variables that make up the independent variable "\% exports financed" do not explain oscillations in performance. The same was true of the dummy variable that had no significant association with performance.

Finally, model 3 shows the associations with international competitiveness of SMEs. These correlations were calculated in order to test whether the more SMEs use financial incentives the better their export competitiveness would be.

Analysis of the influence of financial incentives on Santa Catarina's exporting SMEs' international competitiveness revealed that once more only the variable "use of Incentives" had a significant influence. The variables for " $\%$ Exports Financed" were not significant and the dummy variables were also not significant. Thus, exclusively with relation to financial incentives, there was a correlation with oscillations in the export performance of the SMEs studied.

Therefore, it can be hypothesized that use of financial incentives helps DOI, export performance and international competitiveness but that financing a greater percentage of sales and finance instruments like ACC, ACE, Proex and Proger does not imply better DOI, export performance or international competitiveness. This result can be comprehended by the fact that this study investigated SMEs' export performance, not their financial performance, in which case the results may well have been different. This inference is supported by the qualitative results, since businesses that responded to the survey mentioned that financial incentives are very important for acquiring working capital, but do not reflect directly on performance. 
$90 \%$ of the investment).

Source: Compiled by the authors from information released by BB (2011) and SEBRAE/SC (2011).

\section{FINANCIAL INCENTIVES FOR EXPORTING}

ACC -

(Advances on

Currency

Exchange

Contracts)

ACE -

(Advances on

Foreign

Currency

Receivables)

ROEX -

(Program for

Export

Financing)

These are advances made against exchange rate contracts. The beneficiary is paid in Brazilian currency against a future export contract. The ACC is paid at the pre-shipment stage and is designed to inject resources to cover the costs of production, packaging and shipping of merchandise. Advances can be of up to $100 \%$ of the contract value. The repayment terms of these advance are for up to 360 days. These transactions are exempt from the Brazilian tax on financial operations (IOF).

These are advances made in Brazilian currency against an export contract with payment in the future. The difference between this and an ACC is that in this case payment is only made when merchandise has already shipped. The advance can be of up to $100 \%$ of the contract value and the repayment term is up to 180 days.

According to Banco do Brasil (BB) PROEX loans are only issued by $\mathrm{BB}$ using Brazilian treasury resources (BANCO DO BRASIL, 2011). Repayment terms can be from 60 days to 10 years, depending on the merchandise exported. Companies that export goods and services and have annual revenues of up to R\$ 600 million are eligible for PROEX funding. The proportion of the export contract that can be financed is $100 \%$ for loans with settlements of up to 2 years or up to $85 \%$ of the export value for longer term loans.

PROGER-

(Revenue and Employment Generation Program )
PROGER is a program run by the Brazilian ministry of employment's worker's assistance fund (FAT) with the objective of funding projects and investments that involve job creation, thereby enabling micro and small companies to achieve sustained growth, opening new business ventures and expanding or improving their enterprises. Funding is available from BB or the Caixa Econômica Federal (also controlled by the Brazilian government), with similar requirements, and benefits are as follows: interest rates of $0.85 \%$ per month, loan values of up to $\mathrm{R} \$ 400,000.00$ (limited to between 80 and

\section{Conclusion}

This paper sought to evaluate whether financial incentive programs offered to domestic companies influence the degree of internationalization, export performance or the international competitiveness of SMEs in Santa Catarina, Brazil.

The study raised three research questions: 1) Whether the more exporting SMEs utilize financial incentives, the higher their DOI would be; 2) Whether the more exporting SMEs utilize financial incentives, the better their export performance would be; and 3) Whether the more exporting SMEs utilize financial incentives, the better their international competitiveness would be. The results suggest the following answers:

The results show that 1) The use of financial incentives influences growth of DOI. However, neither the percentages of sales financed, nor instruments such as ACC, ACE, Proex or Proger, have an influence on DOI, export performance or international competitiveness.

It can therefore be perceived that use of incentives improves DOI, export performance and competitiveness, but the incentives themselves, do not have an influence on these constructs. These results demonstrate that there is still much to investigate in this area, testing other indicators of the benefit of financial incentives on DOI, export performance and international competitiveness of SMEs. These results highlight an important gap in research in the area of international business, bearing in mind the importance of the subject to SMEs and the scarcity of studies dealing with the subject.

The results also show that from the perspective of those who manage SMEs, the incentives are important, but companies must achieve competitiveness for themselves. They also see the lack of information on available resources and Brazilian red tape as obstacles that continue to prevent them from taking advantage of the fiscal benefits offered by the Brazilian government. One inference of relevance to future studies is that analysis of the responses showed that the financial incentive programs are purely focused on

Revista de Negócios, v. 20, n. 2, p. 31-39, April, 2015. 
promoting exports and not on facilitating internationalization of companies.

It can be observed that the Brazilian government has attempted to develop measures to help SMEs to export, but that these actions still appear too small in relation to companies' concerns. Small and medium enterprises need programs that stimulate internationalization of companies, rather than just boosting exports.

\section{References}

ALMEIDA, A. Internacionalização de empresas brasileiras, perspectivas e riscos. (FDC), Elsevier: São Paulo, 2007

BANCO DO BRASIL. Brasília. http://www.bb.com.br/exportacao (accessed July 02, 2011)

BANCO NACIONAL DO DESENVOLVIMENTO ECONÔMICO E SOCIAL. http://www.bnds.gov.br (accessed July 02, 2011)

COOPER, D. R.; KLEINSCHMIDT, E. J. The impact of export strategy on export sales performance. Journal of International Business Studies, Vol.16, p. 37-55, Spring, 1985

CZINKOTA, M.; RONKAINEN, I. Internacional Marketing. Fourth Worth: The Dryden Press, 1998.

DÖRRENBÄCHER, C. Measuring corporate internationalization: a review of measurement concepts and their use. Review of European Economic Policy, Vol.35, núm.13, p. 119-126, 2000.

FEDERAÇÃO DAS INDÚSTRIAS DE SANTA CATARINA - FIESC DIAGNÓSTICO EXPORTADOR - 2005 a 2011. Florianópolis: FIESC

FLEURY, A. FLEURY, M. T.L. Brazilian Multinationals - $\quad$ Competence for Internationalization. Cambridge University Press.2011.

FLORIANI, D. E. O grau de internacionalização, as competências e o desempenho da pequena e média empresa brasileira. 307p. Tese de Doutorado em Economia, Administração e Contabilidade, Universidade de São Paulo,(2010

FLORIANI, D. E.; FLEURY, M.T. O Efeito do Grau de Internacionalização nas Competências Internacionais e no Desempenho Financeiro da PME Brasileira. Revista de
Adminsitração Contemporânea, Vol.16, núm.3, p. 438-458, (2012.

FORTE, S. H. A. C.; SETTE JR, E. L. M.Internacionalização de empresas: o caso do setor de rochas ornamentais e de revestimento do Estado do Ceará. In: ENCONTRO ANUAL DA ASSOCIAÇÃO NACIONAL DOS PROGRAMAS DE PÓS-GRADUAÇÃO EM ADMINISTRAÇÃO, 29. Brasília. Anais... Brasília: ANPAD. (CD-Rom), 2005

FUNDAÇÃO DOM CABRAL (FDC). Repensando as estratégias globais: internacionalização em tempos de incertezas econômicas mundiais. Relatório de Pesquisa. Minas Gerais: Fundação Dom Cabral, 2010.

Garcia, L. M. Exportador: rotinas e procedimentos, incentivos e formação de preços, $9^{\text {a }}$ Edición, Aduaneiras, São Paulo, 2007.

GOMES, G.; SILVEIRA, A.; AMAL, M. Internacionalização de Pequenas e Médias Empresas: Estudo da Produção Científica em Periódicos Internacionais (2000-2008). In: VI Encontro de Estudos em Estratégia. Recife-PE, 2009.

JOHANSON, J.; VAHLNE, J. E.. Business Relationship Learning and commitment in the Internationalization Process. Journal of International Entrepreneurship 1, p. 83-101, 2003.

JOHANSON, J.; WIEDERSHEIM-PAUL, F. The internationalisation process of the firms: four Swedish case studies. Journal of Management Studies, 1975.

JOHANSON, J.; VAHLNE, J. E. The Internationalization Process of the Firm- A model of Knowledge Development and Increasing Foreign Market Commitment. Journal of International Business Studies, 1977.

KUME, H. A política de importação no Real e a estrutura de proteção efetiva. Texto para discussão IPEA, núm 423, 23 p., maio,1996.

LOPEZ, J. M. C. e GAMA, MComércio Exterior Competitivo. $3^{\text {a }}$ Edición. Aduaneiras, São Paulo, (2007.

MCDOUGALL, P. P.; OVIATT, B. M. Toward a theory of international New Ventures. Journal of International Bussiness Studies, first quarter., . 1994.

MINISTÉRIO

DO

DESENVOLVIMENTO DA INDÚSTRIA E COMÉRCIO EXTERIOR. http://www.desenvolvimento.gov.br/sitio/interna/i

Revista de Negócios, v. 20, n. 2, p. 31-39, April, 2015. 
nterna.php? area $=5 \&$ menu $=1444 \&$ refr $=603$.

(accessed June 28, 2012).

MOREIRA, L. F. Modelo para determinação do grau de globalização da empresa. Tese (doutorado) - Universidade de São Paulo, São Paulo, 2009.

OVIATT, B. McDOUGALL, P. A framework for understanding accelerated international entrepreneurship. In: RUGMAN, A.; WRIGHT, R. Research in global stratetegic management: international entrepreneurship. Stamford, CT: JAI Press Inc. p. 23-40, 1999

ROCHA, A. Por que as empresas brasileiras não se internacionalizam? In: ROCHA, A. (org.). As novas fronteiras: a multinacionalização das empresas brasileiras. Mauad, Rio de Janeiro, 2003. 